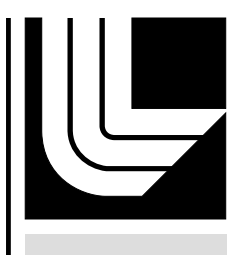

LAW RENCE LIVERMORE N A T IO N A L LABORATORY

\section{Indirect Drive Warm-Loaded Ignition Target Design}

T. P. Bernat, C. R. Gibson

September 7, 2004 
This document was prepared as an account of work sponsored by an agency of the United States Government. Neither the United States Government nor the University of California nor any of their employees, makes any warranty, express or implied, or assumes any legal liability or responsibility for the accuracy, completeness, or usefulness of any information, apparatus, product, or process disclosed, or represents that its use would not infringe privately owned rights. Reference herein to any specific commercial product, process, or service by trade name, trademark, manufacturer, or otherwise, does not necessarily constitute or imply its endorsement, recommendation, or favoring by the United States Government or the University of California. The views and opinions of authors expressed herein do not necessarily state or reflect those of the United States Government or the University of California, and shall not be used for advertising or product endorsement purposes.

This work was performed under the auspices of the U.S. Department of Energy by University of California, Lawrence Livermore National Laboratory under Contract W-7405-Eng-48. 


\section{Indirect Drive Warm-Loaded Ignition Target Design}

This document summarizes the Indirect Drive Warm-Loaded Ignition Target design. These targets either use a fill tube or the capsule is strong enough to withstand the room temperature pressure of the DT fuel. Only features that affect the design of the NIF Cryogenic Target System (NCTS) are presented. The design presented is the current thinking and may evolve further. The NCTS should be designed to accommodate a range of targets and target scales, as described here.

The interface location between the target and the NCTS cryostat is at the target base / gripper joint, the tamping gas gland/gland joint, and the electrical plug/receptacle joint.

\section{$\underline{\text { Target Geometry }}$}

Overall: Two possible versions of an Indirect Drive Warm-Loaded Ignition Target design are shown in Figures 1 and 2. Figure 1 shows an Indirect Drive Warm-Loaded Ignition Target with separate electrical and gas connectors. In this design, a tool (not shown) would be used to support the target base and the electrical and gas connectors until they were installed in the NCTS. Figure 2 shows an Indirect Drive Warm-Loaded Ignition Target with integral electrical and gas connectors. In this design, the electrical and gas connectors are built into the back of the target base (not shown in figure).

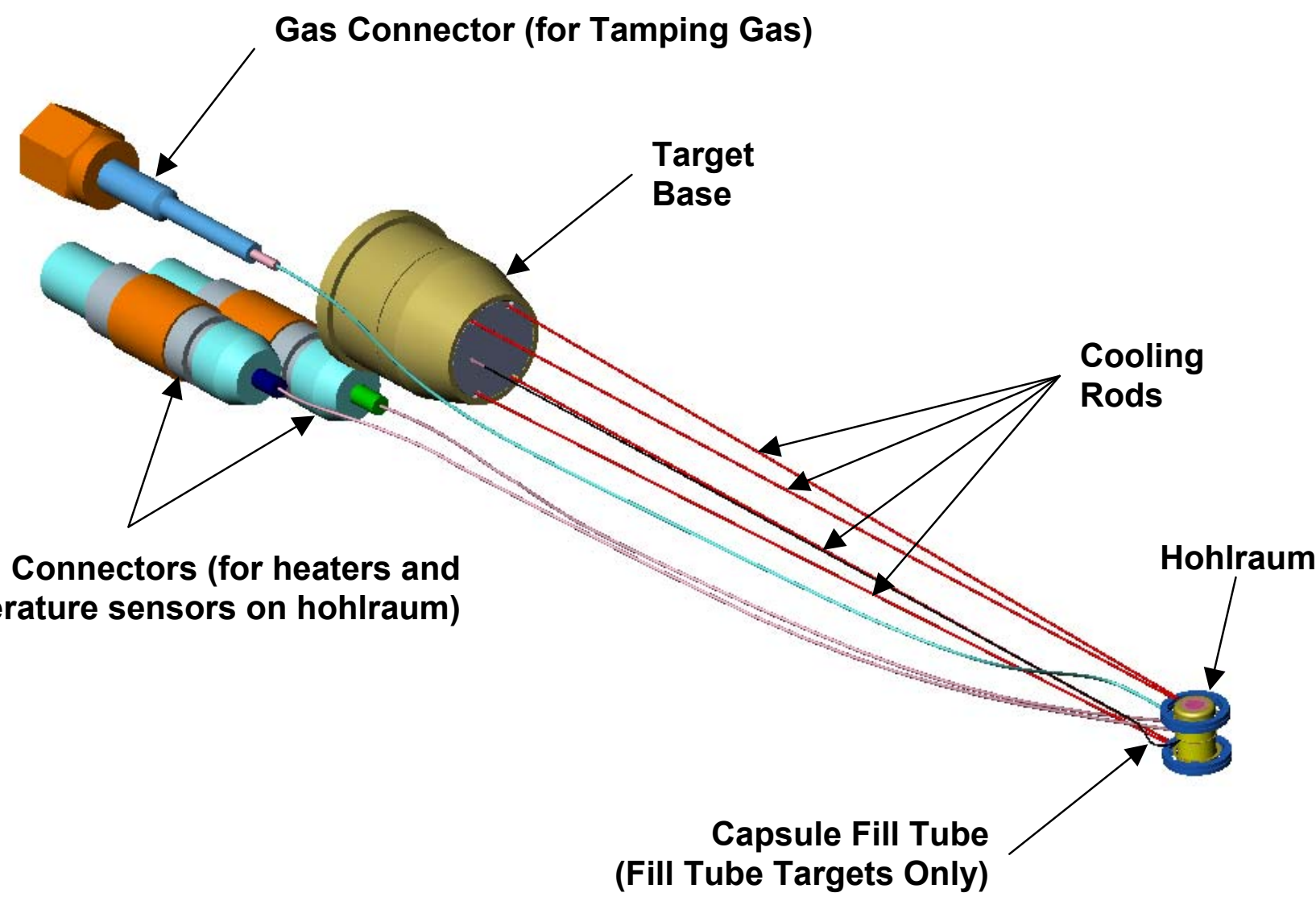

Figure 1. Indirect Drive Warm-Loaded Ignition Target with Separate Electrical and Gas Connectors 


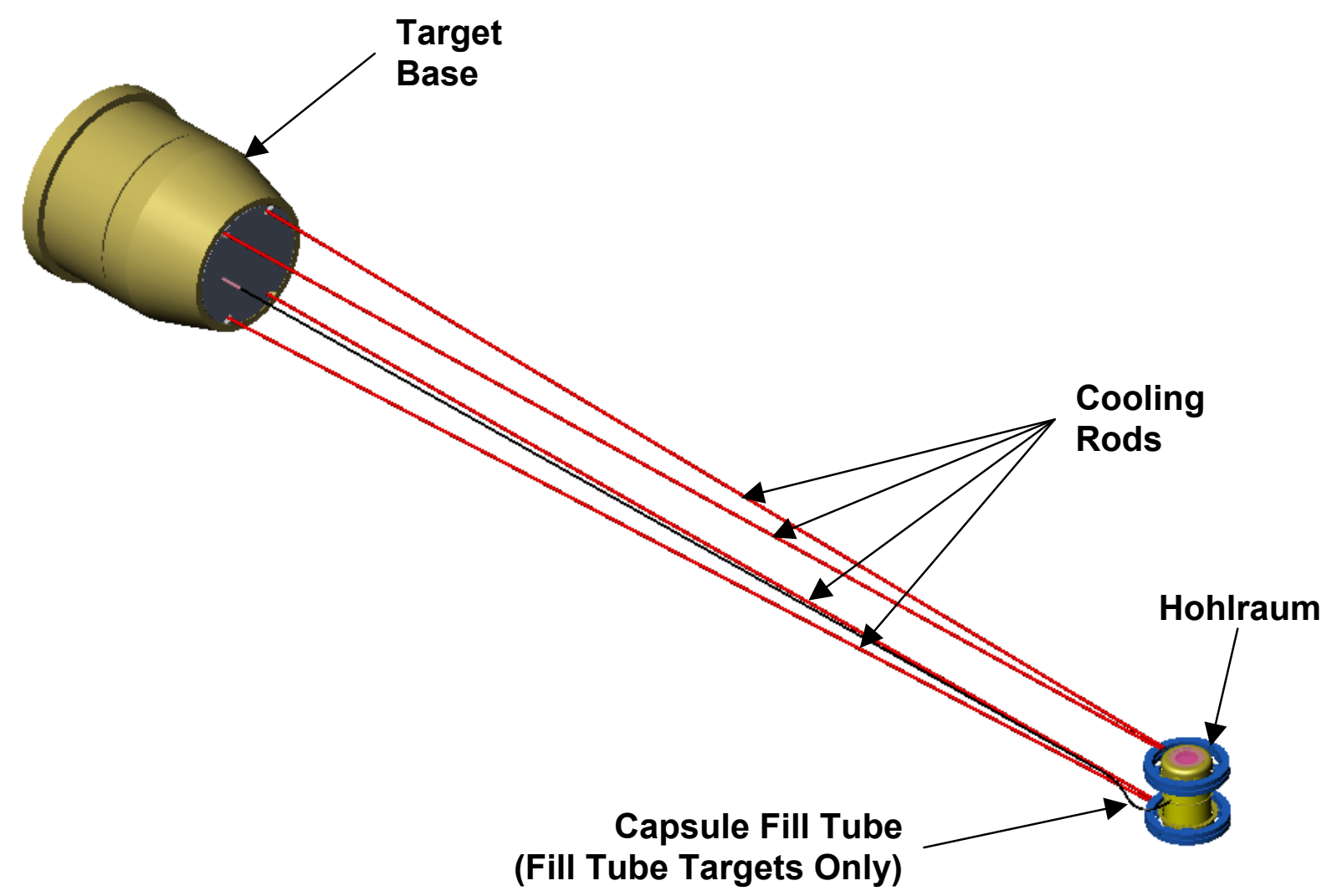

Figure 2. Indirect Drive Warm-Loaded Ignition Target with Integral Electrical and Gas Connectors

The lowest bending mode of the overall target assembly is TBD. The maximum allowable impact load to the overall target assembly is TBD.

Capsule: Capsule designs which are being considered for indirect drive warm-loaded ignition targets are shown in Figure 3 and Table $1^{1,2,3}$. The capsule materials include $\mathrm{CH}$, polyimide, and beryllium w/ copper. The $\mathrm{CH}$ and polyimide capsules have fill-tubes while the Be capsules can be either filled using fill-tubes or filled by the "drill, fill \& plug" method. Note that the geometries given are for "Scale 1" designs. The figure shows a range on the cold-loaded targets from as small as "Scale 0.5 " to as large as "Scale 1.4". However target designers have asked that targets as large as a hohlraum length of $25 \mathrm{~mm}$ (Scale 2.63) be accomodated. ${ }^{8}$

The composition of the DT fuel shall be:

Tritium Concentration: $\quad(47-53 \%)$ measured to $<2 \%$

Protium Concentration: $\quad(<1 \%)$ measured to $\sim 0.3 \%$

$\mathrm{He}^{3}$ Density:

$(<0.1 \mathrm{mg} / \mathrm{cc}$ within $0.025 \mathrm{mg} / \mathrm{cc}$ of nominal) measured to $0.01 \mathrm{mg} / \mathrm{cc}$

Other Species:

$(<0.002 \%)$ measured to $0.002 \%$ 


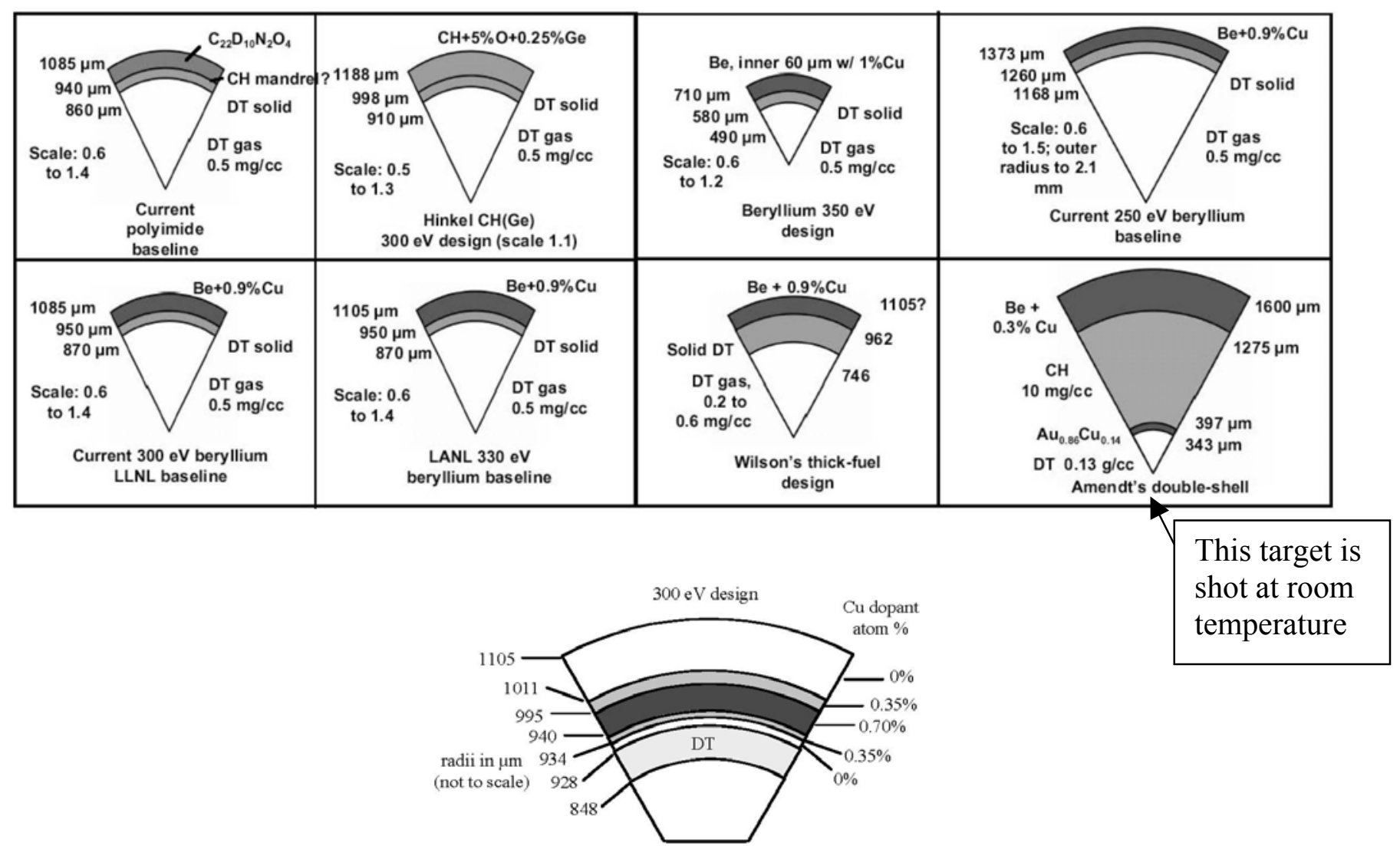

Be Capsule with Graded $\mathrm{Cu}$ Dopant

Figure 3. Scale 1 NIF Indirect Drive Warm-Loaded Ignition Capsule Designs (References 1, 2 and 3) 
TABLE 1. Geometry, Curies, Fill Pressures, and DT Gas Density and Temperature for Indirect Drive Warm-Loaded Targets

\begin{tabular}{|c|c|c|c|c|c|c|c|c|c|c|c|c|}
\hline Design & Scale & $\begin{array}{l}\text { Hohl- } \\
\text { raum } \\
\text { Dia. }\end{array}$ & $\begin{array}{l}\text { Hohl- } \\
\text { raum } \\
\text { Length }\end{array}$ & $\begin{array}{c}\text { Capsule } \\
\text { Outer } \\
\text { Radius }\end{array}$ & \begin{tabular}{|c} 
DT \\
Ice \\
Outer \\
Radius
\end{tabular} & $\begin{array}{c}\text { DT } \\
\text { Ice } \\
\text { Inner } \\
\text { Radius }\end{array}$ & $\begin{array}{c}\text { Aspect } \\
\text { Ratio }\end{array}$ & $\begin{array}{l}\text { \# of } \\
\text { Curies } \\
\text { (Ref 9) }\end{array}$ & $\begin{array}{l}\text { DT } \\
\text { Reservoir } \\
\text { Volume* }\end{array}$ & $\begin{array}{c}\text { DT } \\
\text { Reservoir } \\
\text { Fill } \\
\text { Pressure } \\
\text { a 300K* } \\
\end{array}$ & \begin{tabular}{|c} 
DT \\
Gas \\
Density \\
At \\
Shot \\
\end{tabular} & \begin{tabular}{|c} 
DT \\
Gas \\
Temp \\
At \\
Shot \\
\end{tabular} \\
\hline & & $(\mathbf{m m})$ & $(\mathbf{m m})$ & $(\mu \mathbf{m})$ & $(\mu \mathrm{m})$ & $(\mu \mathrm{m})$ & & $(\mathbf{C u})$ & (cc) & (psia) & $(\mathrm{mg} / \mathrm{cc})$ & $(\mathbf{K})$ \\
\hline \multirow[t]{3}{*}{ Current Polyimide Baseline } & 0.6 & 3.3 & 5.7 & 651 & 564 & 516 & .085 & 0.258 & TBD & TBD & 0.5 & 19.3 \\
\hline & 1.0 & 5.5 & 9.5 & 1085 & 940 & 860 & “ & 1.192 & TBD & TBD & “ & “ \\
\hline & 1.4 & 7.7 & 13.3 & 1519 & 1316 & 1204 & “ & 3.272 & TBD & TBD & “ & “ \\
\hline \multirow[t]{3}{*}{ Hinkel $\mathrm{CH}(\mathrm{Ge}) 300 \mathrm{eV}$} & 0.5 & 2.8 & 4.8 & 499 & 598.8 & 455 & .088 & 0.184 & TBD & TBD & 0.5 & 19.3 \\
\hline & 1.0 & 5.5 & 9.5 & 1188 & 998 & 910 & “ & 1.474 & TBD & TBD & “ & “ \\
\hline & 1.3 & 7.2 & 12.4 & 1544 & 1297 & 1183 & “ & 3.238 & TBD & TBD & “ & “ \\
\hline \multirow[t]{3}{*}{ Beryllium 350eV Design } & 0.6 & 3.3 & 5.7 & 426 & 348 & 294 & .155 & 0.103 & TBD & TBD & 0.5 & 19.3 \\
\hline & 1.0 & 5.5 & 9.5 & 710 & 580 & 490 & “ & 0.475 & TBD & TBD & “ & “ \\
\hline & 1.2 & 6.6 & 11.4 & 852 & 696 & 588 & “ & 0.821 & TBD & TBD & “6 & “ \\
\hline \multirow[t]{3}{*}{ Current 250eV Beryllium Baseline } & 0.6 & 3.3 & 5.7 & 824 & 756 & 701 & .073 & 0.539 & TBD & TBD & 0.5 & 19.3 \\
\hline & 1.0 & 5.5 & 9.5 & 1373 & 1260 & 1168 & “6 & 2.494 & TBD & TBD & " & " \\
\hline & 1.5 & 8.3 & 14.3 & 2060 & 1890 & 1752 & “6 & 8.419 & TBD & TBD & “ & " \\
\hline \multirow{3}{*}{$\begin{array}{l}\text { Current } 300 \mathrm{eV} \text { Beryllium LLNL } \\
\text { Baseline }\end{array}$} & 0.6 & 3.3 & 5.7 & 651 & 570 & 522 & .084 & 0.263 & TBD & TBD & 0.5 & 19.3 \\
\hline & 1.0 & 5.5 & 9.5 & 1085 & 950 & 870 & "6 & 1.219 & TBD & TBD & “ & “" \\
\hline & 1.4 & 7.7 & 13.3 & 1519 & 1330 & 1218 & 6 & 3.345 & TBD & TBD & $" 6$ & " \\
\hline \multirow[t]{3}{*}{ LANL 330eV Beryllium Baseline } & 0.6 & 3.3 & 5.7 & 663 & 570 & 522 & .084 & 0.263 & TBD & TBD & 0.5 & 19.3 \\
\hline & 1.0 & 5.5 & 9.5 & 1105 & 950 & 870 & “ & 1.219 & TBD & TBD & “ & “ \\
\hline & 1.4 & 7.7 & 13.3 & 1547 & 1330 & 1218 & “ & 3.345 & TBD & TBD & “ & “ \\
\hline \multirow[t]{2}{*}{ Wilson's Thick-Fuel Design } & 1.0 & 5.5 & 9.5 & 1105 & 962 & 746 & .225 & 2.939 & TBD & TBD & 0.2 & 17.5 \\
\hline & 1.0 & 5.5 & 9.5 & 1105 & 962 & 746 & “ & 2.907 & TBD & $\mathrm{TBD}$ & 0.6 & 19.6 \\
\hline Amendt's Double-Shell & 1.0 & 5.5 & 9.5 & 1600 & 343 & $\mathrm{~N} / \mathrm{A}$ & $\mathrm{N} / \mathrm{A}$ & 0.126 & TBD & $\mathrm{TBD}$ & 1300 & 300 \\
\hline \multirow[t]{3}{*}{$\begin{array}{l}300 \mathrm{eV} \text { Be Capsule with Graded } \mathrm{Cu} \\
\text { Dopant }\end{array}$} & 0.6 & 3.3 & 5.7 & 663 & 557 & 509 & .086 & .2509 & $\mathrm{TBD}$ & TBD & 0.5 & 19.3 \\
\hline & 1.0 & 5.5 & 9.5 & 1105 & 928 & 848 & 6 & 1.161 & TBD & $\mathrm{TBD}$ & $“$ & “6 \\
\hline & 1.4 & 7.7 & 13.3 & 1547 & 1299 & 1187 & “ & 3.184 & TBD & TBD & $“$ & “ \\
\hline Haan's Upper Limit ${ }^{8}$ & 2.63 & 14.5 & 25.0 & 2908 & 2442 & 2232 & “ & 21.10 & TBD & TBD & “ & \\
\hline
\end{tabular}

\footnotetext{
* For fill-tube targets only.
} 
The DT gas density at shot time shall be controlled to $<0.01 \mathrm{mg} / \mathrm{cc}$, which corresponds to a temperature of $<\sim 50 \mathrm{mK}$. The required temperature of the capsule is set by the DT vapor density, as shown in Figure $4{ }^{7}$ For example, $0.5 \mathrm{mg} / \mathrm{cc}$ corresponds to $\sim 19.3 \mathrm{~K}$. Target performance is improved as gas density is decreased, with better performance at $0.3 \mathrm{mg} / \mathrm{cc}$ and optimum performance at $0.1 \mathrm{mg} / \mathrm{cc}$. Layering experiments, however, have shown that the DT ice inner surface roughens as the gas density (temperature) is decreased. The NCTS design should provide operation at a range of gas densities (temperatures) between $0.1 \mathrm{mg} / \mathrm{cc}$ and the DT triple point to allow optimization of target performance.

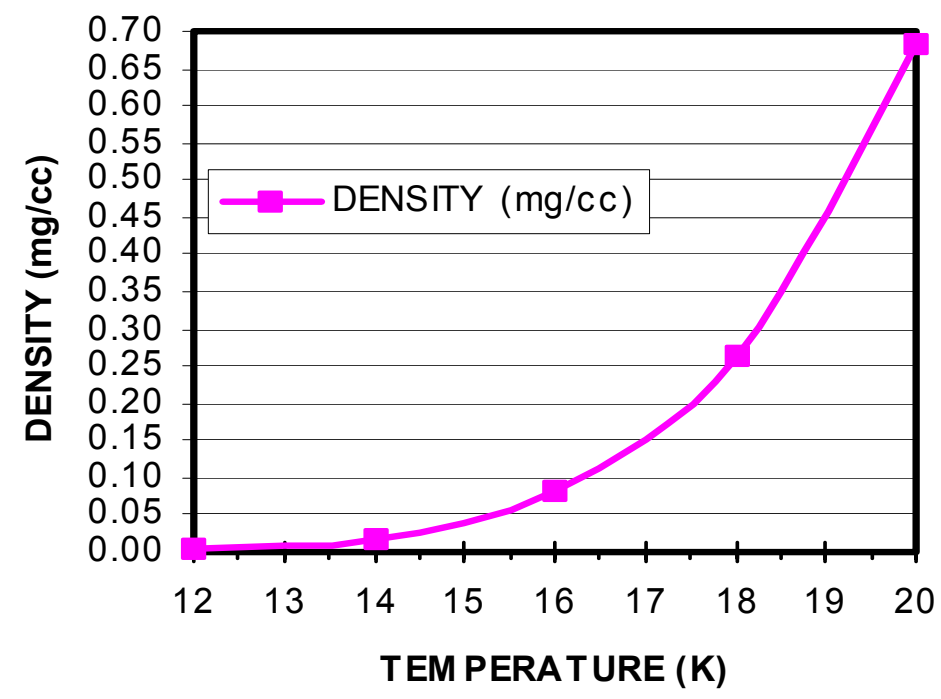

Figure 4. DT Saturated Vapor Density

The average DT solid layer thickness shall be within 0.5 micron of specified and measured to an accuracy of 0.25 micron. ${ }^{4}$ For targets with fill tubes, the required room temperature reservoir fill pressures is set by the reservoir volume and DT solid layer thickness required. Pressures for the capsules in Figure 3 and Table 1 range from TBD to TBD psia at room temperature $(300 \mathrm{~K})$. The DT gas pressure inside the reservoir shall be known to an accuracy of TBD\%.

Hohlraum: The hohlraum is a gold cylinder with a $5.5 \mathrm{~mm}$ diameter and a $9.5 \mathrm{~mm}$ length with a wall thickness of 100 micron (Scale 1) ${ }^{2}$, however, other materials (e.g. cocktail hohlraums) and wall thicknesses are possible. The hohlraum scale will vary directly with the capsule scale. The laser entrance hole (LEH) at the end of each hohlraum is $\sim 3.0 \mathrm{~mm}$ in diameter and will, however, not change with scale. Hohlraum temperature equalizing rings, which are designed to equalize the radial temperature distribution around the hohlraum, are connected to the top and bottom of the hohlraum. The temperature stability of the equalizing rings shall be $+/-1 \mathrm{mK}$ or better. ${ }^{5}$

The distance from the hohlraum centerline to the target base / gripper interface plane is TBD.

During layering, the hohlraum will be filled with $\mathrm{He}$ gas at a pressure of 10 to $50 \mathrm{mtorr}$. This gas is used to provide a thermal conduction path between the capsule and the hohlraum wall. At shot time, the hohlraum will be filled with $\mathrm{He}$ or $\mathrm{H}_{2}+\mathrm{He}$ tamping gas at a nominal density of between $1.25 \mathrm{mg} / \mathrm{cc}$. The density of the tamping gas ranges from 0.75 and $1.5 \mathrm{mg} / \mathrm{cc}^{3}{ }^{3}$ The density shall be measured to $+/-$ 
$10 \%{ }^{4}$ The required time to fill the hohlraum with tamping gas is TBD. The composition of the gas shall be measured to $10 \%$ for all atomic fractions. ${ }^{4}$

The tamping gas is filled through a TBD diameter fill tube. The tamping gas fill tube extends from the gas interface fitting to the hohlraum.

Cooling Rods: The cooling rods connect the hohlraum to the target base. Figure 1 shows four cooling rods, but designs with two rods have been proposed. Designs with truss-like (radio tower) cooling rods have also been proposed. The rods will be either sapphire or high-purity aluminum. The rods will have a diameter of approximately $0.5 \mathrm{~mm}$ and a length of TBD $\mathrm{mm}$.

Target Base: The target base connects the target assembly to the NCTS Ignition Target Inserter and Cryostat (I-TIC). For targets with fill tubes, the target base also contains the DT reservoir, as shown in Figure 5.

The target base shall include blast shield material as shown in Figure 4. This auxiliary blast shield shall intercept shot products which come through holes in the main blast shield. The holes in the main blast shield are to allow for penetration of the cooling rods, fill tube(s), and electrical wires.

The interfaces between the target base and the NCTS are:

- Alignment interface: TBD (holes and/or slots for alignment pins)

- Mechanical interface: TBD (collar for NCTS gripper to hold the target base)

- Thermal interface:

- Heat Load at Temperature: $200 \mathrm{~mW}$ at $7 \mathrm{~K}^{5}$

- Temperature stability of interface: $+/-10 \mathrm{mK}$

- Temperature ramp-rate of interface: Variable between 0.5 and $10 \mathrm{mK} / \mathrm{min}$.

For targets with fill-tubes:

- Fill Line interface: TBD (tube used during reservoir fill)

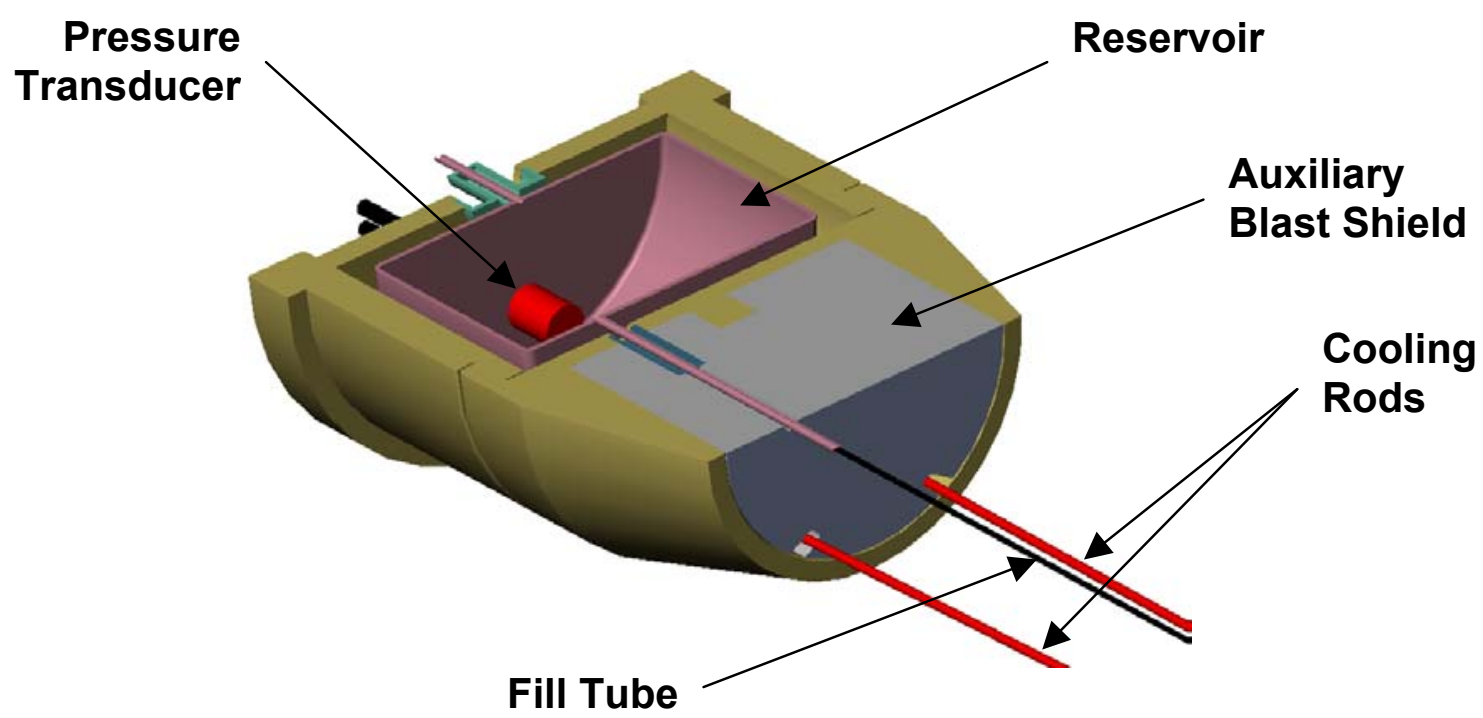

Figure 5. Cross Section of Target Base for Targets With Fill Tubes 
For Indirect Drive Warm-Loaded Ignition Target with Separate Electrical and Gas Connectors:

Electrical Interface: The electrical interface between the target and the NCTS uses the same connectors that are used on the N-TIC (previously known as the Mk-1). These are two (2) LEMO quick-disconnect circular connectors, each with 14 contacts. The plug (target side) is LEMO part \#FGG-1B-3-14-CLAD and the receptacle (NCTS side) is LEMO part \# EGG-1B-3-14-CLAD.

Gas Interface: The gas interface, used to supply tamping gas to the hohlraum, also uses the same fittings as the N-TIC. The fittings are $1 / 8$ inch VCR metal gasket face seal fittings by the Cajon Company. The target side shall use female VCR nuts and NCTS side shall use male nuts.

For Indirect Drive Warm-Loaded Ignition Target with Integral Electrical and Gas Connectors:

Electrical Interface: TBD

Gas Interface: TBD

\section{Characterization and Layering}

The DT ice layer inside the capsule shall be characterized from two orthogonal directions. One characterization axis is vertical through the laser entrance hole windows.

The other characterization axis is transverse - orthogonal to both the hohlraum axis and the target positioner axis. The sides of each hohlraum will have slots to allow for characterization in this transverse axis. These slots will be arranged in a "star-burst" pattern as shown in Figure 5. ${ }^{6}$ The NCTS must provide a suitable characterization capability for these two orthogonal views.

The characterization methods used will be shadowgraphy and phase contrast $\mathrm{x}$-ray. The time required to characterize a target using shadowgraphy is TBD. During this shadowgraphy characterization period, the maximum capsule motion must be less than TBD microns.

The time required to characterize a target using phase contrast $\mathrm{x}$-ray is TBD. During this phase contrast $\mathrm{x}$-ray characterization period, the maximum capsule motion must be less than TBD microns.

Layering of the DT ice shall be done by natural beta layer and infrared (IR) layering. The maximum power required for IR layering is TBD $\mathrm{Q}_{\mathrm{DT}}$. The IR light shall enter the hohlraum through TBD [either through the hohlraum wall or through the LEHs]. 

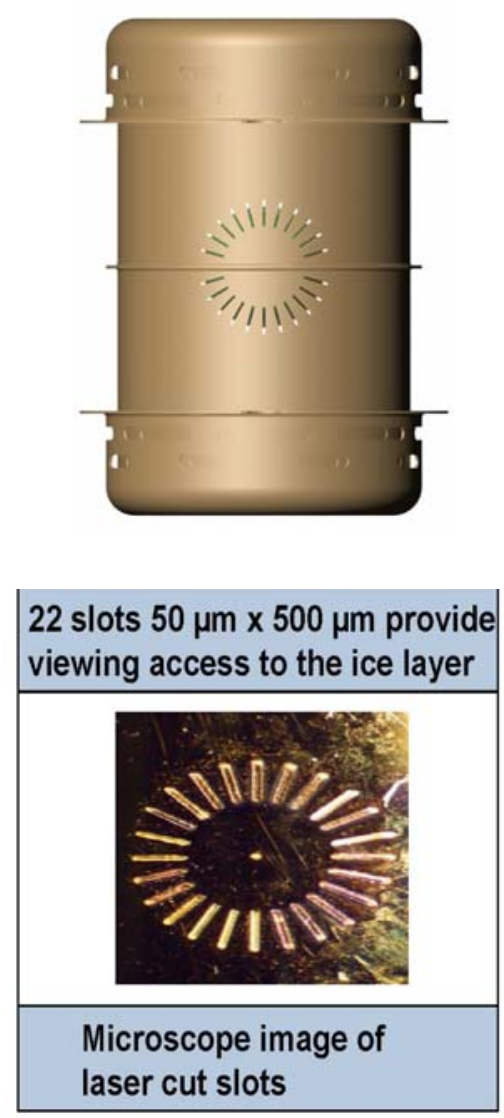

Figure 5. Star-burst Characterization Slots.

\section{$\underline{\text { References }}$}

1. HAAN, STEVE, “Target Design and Implosions," Presentation to Defense Science Board Task Force, July 12, 2004

2. HAAN, STEVE, et. al. "Update on NIF Indirect Drive Ignition Target Fabrication Specifications," Fusion Science and Technology. 45, 69 (2004)

3. HAAN, STEVE, et. al. "Update on Ignition Target Fabrication Specifications," Fusion Science and Technology. 41, 164 (2002)

4. STEPHENS, RICHARD, HAAN, S.W. and WILSON, D.C. "Characterization Specifications for Baseline Indirect Drive NIF Targets," Fusion Science and Technology. 41, 226 (2002)

5. HAID, BEN, memo on "Confirmation of NCTS ID Target Requirements" to John Moody, 5/20/2004

6. MOODY, JOHN, "Cryogenic Studies in the NIF/ICF Program at LLNL." Presentation to Defense Science Board Task Force, July 12, 2004 
7. SOURS, P. CLARK, "Hydrogen Properties for Fusion Energy", p. 57, 1986

8. HAAN, STEVE, Private communication with Chuck Gibson, 8/2/2004

9. ALEXANDER, NEIL, MathCAD worksheet using Equation 16.7 (page 206) of Reference 7. 